\title{
AN EFFECT OF LIFE SKILLS TRAINING PROGRAMME ON THE
}

\section{AWARENESS LEVEL OF KGBVS}

\section{B. PRASHANTHI}

College of Home Science, Saifabad, Hyderabad, Andhra Pradesh, India

\begin{abstract}
Life skills training programme take into account psychosocial competencies and interpersonal skills that help students to take right decisions, solve problems, think critically and creatively, communicate effectively, build healthy relationships, empathize with others, and cope with managing their lives in a healthy and productive manner. KGBV's Schools under Jogulama Gadwal district were selected purposefully for study. The sample was comprised of 60 adolescents in the age range of 13-15 years (class VIII, IX \& X students). Life skills inventory consisting of 65 items was developed covering all the nine areas of LSE. The results revealed that awareness levels of KGBV's girls have increased in all the nine domains of LSE after the training programme.

KEYWORDS: Life Skills Training, KGBV's Schools \& Students
\end{abstract}

Received: Sep 21, 2018; Accepted: Oct 12, 2018; Published: Nov 01, 2018; Paper Id.: IJESRDEC20186

\section{INTRODUCTION}

Life skills are the abilities for adaptive and positive behaviour that enables individuals to deal effectively with the demands and challenges of everyday life". Life skills are innumerable and the nature of life skills is likely to differ across culture and settings. However, analysis of the life skills suggests that there is a core set of skills that are at the heart of skills based initiatives for the promotion of the health and well-being of children and adolescents. World Health Organization 1997) described ten core life skills i. e. Decision Making, Problem Solving, Creative Thinking, Critical Thinking, Effective Communication, Inter- personal relationship skills, Self Awareness, Empathy, Coping with Emotions and Stress. Life skills enable individuals to translate knowledge, attitudes and values into actual abilities.

Kasturba Gandhi Balika Vidyalaya (KGBV) Scheme was launched by the Government of India to make the education system more responsive to the needs of marginalised girls and to enhance their access and retention. Under the scheme, residential schools for girls at upper primary levels (VI to X) were set up in the Educationally Backward Block (EBB) s, towns and minority concentrated areas all over the country. The scheme provides upper primary level education for girls who are either drop out or never enrolled in the age group of 10-14 years belonging to Scheduled Castes (SC), Scheduled Tribes (ST), Other Backward Classes (OBC), Minority communities and children of families of Below Poverty Line (BPL).

Arati (2016) studied the influence of personal variables on core affective life skills of adolescents, it was shown that the order of birth and family income has significant influence on interpersonal relationship dimension of life skills. Gender, number of siblings and family type has no significant influence on core affective life skills. Good support from the family can equip the children with skills for life. 
Singh and Kaur (2015) found there is reported a rise in teen stress with a tremendous shift in the structure of society, which can be because of disturbed family dynamics, peer pressure, inability to cope with studies, drug abuse, lack of competence, etc. leading to maladaptive behaviour.

Subashree and Nair (2014) noted that with cultures and lifestyles in transition, many young people are not adequately equipped with life skills to help them deal with the augmented demands and stresses they experience. Effective use of Life-Skills can influence the way children feel about others and themselves, which in turn can add to the children's self confidence and self-esteem (Life-Skills Education and CCE Manual CBSE, 2010). Productivity, self-esteem, self-confidence interpersonal relationships are also affected.

\section{Objective}

To see the effect of training programme on awareness levels of nine domains of Life skills education in KGBV's.

\section{The Increased Awareness Levels of the KGBVs on Life Skills in Decision Making}

Table 1: Effect of Life Skills Training in Decision Making of the KGBVs

\begin{tabular}{|c|c|c|c|c|c|c|c|c|c|}
\hline \multicolumn{10}{|c|}{$\mathbf{9}^{\text {th }}$ class } \\
\hline \multirow{2}{*}{ Test } & \multicolumn{3}{|c|}{$\mathbf{1 0}^{\text {th }}$ class } & \multicolumn{3}{c|}{$\mathbf{8}^{\text {th }}$ class } \\
\cline { 2 - 11 } & Low & Average & High & Low & Average & High & Low & Average & High \\
\hline Pre test & 20 & 25 & 55 & 30 & 50 & 20 & 15 & 50 & 35 \\
\hline Post test & 10 & 30 & 60 & 20 & 25 & 55 & 15 & 20 & 65 \\
\hline
\end{tabular}

- The decision-making skills of the three classes those are $10^{\text {th }}, 9^{\text {th }}$ and $8^{\text {th }}$ in KGBVS. Before intervention, it can be seen that in only $10^{\text {th }}$ class students more than $50 \%$ having high decision making skills. In $9^{\text {th }}$ and $8^{\text {th }}$ class only One-fourth of the sample having high decision making skills.

- The Intervention helped the students to intervention their decision making skills. This can be seen in the graph that more than $60 \%$ of the respondents in $10^{\text {th }}$ class, $55 \%$ in $9^{\text {th }}$ and $65 \%$ in $8^{\text {th }}$ class improved this decision making skills.

\section{The Increased Awareness Levels of the KGBVs on Life Skills in Creative Thinking}

Table 2: Effect of Life Skills Training on Creative Thinking

\begin{tabular}{|c|c|c|c|c|c|c|c|c|c|}
\hline \multicolumn{9}{|c|}{ Creative thinking } \\
\hline \multirow{2}{*}{ Test } & \multicolumn{3}{|c|}{$\mathbf{1 0}^{\text {th }}$ class } & \multicolumn{3}{c|}{$\mathbf{8}^{\text {th }}$ class } \\
\cline { 2 - 11 } & Low & Average & High & Low & Average & High & Low & Average & High \\
\hline Pre test & 15 & 45 & 40 & 20 & 30 & 50 & 20 & 45 & 35 \\
\hline Post test & 10 & 15 & 75 & 15 & 40 & 45 & 15 & 15 & 70 \\
\hline
\end{tabular}

- The creative thinking of the three classes $10^{\text {th }}, 9^{\text {th }}$ and $8^{\text {th }}$ in KGBVS. Before intervention, it can be seen that among the $10^{\text {th }}$ class students $40 \%$ are having creative thinking abilities.

- In $9^{\text {th }}$ and $8^{\text {th }}$ class students more than $15 \%$ are having creative thinking and only $35 \%$ of the sample having creative thinking. The Intervention helped the students to intervention their creative thinking. This can be seen in the figure that more than $75 \%$ of the respondents in $10^{\text {th }}$ class, $45 \%$ in $9^{\text {th }}$ and $70 \%$ in $8^{\text {th }}$ class improved this creative thinking. 
The Increased Awareness Levels of the KGBVs on Life Skills in Effective Communication Skills

Table 3: Effect of Life Skills Training on Communication Skills

\begin{tabular}{|c|c|c|c|c|c|c|c|c|c|}
\hline \multicolumn{10}{|c|}{ Effective Communication Skills } \\
\hline \multirow{2}{*}{ Test } & \multicolumn{3}{|c|}{$\mathbf{1 0}^{\text {th }}$ class } & \multicolumn{3}{c|}{$\mathbf{9}^{\text {th }}$ class } & \multicolumn{3}{c|}{$\mathbf{8}^{\text {th }}$ class } \\
\cline { 2 - 11 } & Low & Average & High & Low & Average & High & Low & Average & High \\
\hline Pre test & 10 & 30 & 60 & 10 & 35 & 55 & 20 & 20 & 60 \\
\hline Post test & 5 & 40 & 55 & 5 & 45 & 50 & 15 & 15 & 70 \\
\hline
\end{tabular}

- Before intervention it can be seen that in $60 \%$ having high effective communication skills. In $9^{\text {th }}$ and $8^{\text {th }}$ classes $5 \%$ of the sample having high effective communication skills.

- Among the three classes of the students $10^{\text {th }}$ and $9^{\text {th }}$ classes students had less effective communication in the intervention and $8^{\text {th }}$ class $70 \%$ respondents having high effective communication skills in the intervention.

The Increased Awareness Levels of the KGBVs on Life Skills in Self-Awareness

Table 4: Effect of Life Skills Training on Self-Awareness

\begin{tabular}{|c|c|c|c|c|c|c|c|c|c|}
\hline \multicolumn{9}{|c|}{ Self-awareness } \\
\hline \multirow{2}{*}{ Test } & \multicolumn{3}{|c|}{$\mathbf{1 0}^{\text {th }}$ class } & \multicolumn{3}{c|}{$\mathbf{9}^{\text {th }}$ class } & \multicolumn{3}{c|}{$\mathbf{8}^{\text {th }}$ class } \\
\cline { 2 - 11 } & Low & Average & High & Low & Average & High & Low & Average & High \\
\hline Pre test & 15 & 50 & 35 & 20 & 20 & 60 & 15 & 20 & 65 \\
\hline Post test & 10 & 40 & 60 & 10 & 30 & 60 & 10 & 40 & 50 \\
\hline
\end{tabular}

- Self awareness skills in the students in KGBVs. Before intervention it can be seen that in only $10^{\text {th }}$ class students $35 \%$ having self awareness. In $9^{\text {th }}$ and $8^{\text {th }}$ students $5 \%$ having self awareness.

- The intervention helped the students to increase their self awareness. This can be seen the graph $60 \%$ of the respondents in $10^{\text {th }}$ class students having more self-awareness, $60 \%$ in the $9^{\text {th }}$ class and $50 \%$ in $8^{\text {th }}$ class improved this self awareness.

The Increased Awareness Levels of the KGBVs on Life Skills in Coping Stress and Emotions

Table 5: Effect of Life Skills Training on Coping Stress and Emotions

\begin{tabular}{|c|c|c|c|c|c|c|c|c|c|}
\hline \multicolumn{10}{|c|}{ Coping Stress and Emotions } \\
\hline \multirow{2}{*}{ Test } & \multicolumn{3}{|c|}{$\mathbf{1 0}^{\text {th }}$ class } & \multicolumn{3}{c|}{$\mathbf{8}^{\text {th }}$ class } & \multicolumn{3}{c|}{ class } \\
\cline { 2 - 11 } & Low & Average & High & Low & Average & High & Low & Average & High \\
\hline Pre test & 15 & 50 & 35 & 25 & 35 & 40 & 30 & 30 & 40 \\
\hline Post test & 10 & 35 & 55 & 20 & 25 & 55 & 20 & 25 & 55 \\
\hline
\end{tabular}

- Coping stress and emotions in KGBVs students. Before intervention it can be seen that in the $10^{\text {th }}$ class students $35 \%$ coping stress and emotions. In $9^{\text {th }}$ and $8^{\text {th }}$ studentsonly $40 \%$ respondents having coping stress and emotions.

- The intervention helped the students to increase their coping stress and emotions. This can be seen in the graph that indicates $55 \%$ of the respondents among the three classes having high coping stress and emotions. 
The Increased Awareness Levels of the KGBVs on Life Skills in Empathy

Table 6: Effect of Life Skills Training on Empathy

\begin{tabular}{|c|c|c|c|c|c|c|c|c|c|}
\hline \multicolumn{9}{|c|}{ Empathy } \\
\hline \multirow{2}{*}{ Test } & \multicolumn{3}{|c|}{$\mathbf{1 0}^{\text {th }}$ class } & \multicolumn{3}{c|}{$\mathbf{9}^{\text {th }}$ class } & \multicolumn{3}{c|}{ class $^{\text {th }}$} \\
\cline { 2 - 11 } & Low & Average & High & Low & Average & High & Low & Average & High \\
\hline Pre test & 10 & 45 & 45 & 15 & 50 & 35 & 20 & 35 & 45 \\
\hline Post test & 5 & 45 & 50 & 10 & 35 & 55 & 15 & 30 & 55 \\
\hline
\end{tabular}

- Empathy in KGBVs students. Before intervention it can be seen that $10^{\text {th }}$ class and $8^{\text {th }}$ class students have $45 \%$ having empathy and $9^{\text {th }}$ class students have $35 \%$ of empathy.

- The intervention helped the students to increase their empathy this can be seen in the graph that $50 \%$ of respondents in the $10^{\text {th }}$ class. In the $9^{\text {th }}$ and $8^{\text {th }}$ classes $55 \%$ having high empathy.

The increased Awareness Levels of the KGBVs on Life Skills in Problem-Solving Skills

Table 7: Effect of Life Skills Training on Problem-Solving Skills

\begin{tabular}{|c|c|c|c|c|c|c|c|c|c|}
\hline \multicolumn{9}{|c|}{ Problem solving skills } \\
\hline \multirow{2}{*}{ Test } & \multicolumn{3}{|c|}{$\mathbf{1 0}^{\text {th }}$ class } & \multicolumn{3}{c|}{$\mathbf{9}^{\text {th }}$ class } & \multicolumn{3}{c|}{$\mathbf{8}^{\text {th }}$ class } \\
\cline { 2 - 11 } & Low & Average & High & Low & Average & High & Low & Average & High \\
\hline Pre test & 15 & 45 & 40 & 20 & 40 & 40 & 15 & 25 & 60 \\
\hline Post test & 10 & 25 & 65 & 15 & 35 & 50 & 10 & 25 & 65 \\
\hline
\end{tabular}

- Problem-solving is one of the major components in the life skills education. Before intervention it can be seen that $10^{\text {th }}$ and $9^{\text {th }}$ classes students $40 \%$ having problem solving skills. In $8^{\text {th }}$ class $60 \%$ having high problem solving skills.

- The intervention helped the students to increase their problem solving skills. This can be seen in the graph that $65 \%$ having high problem solving skills. In $9^{\text {th }}$ and $8^{\text {th }}$ classes increase their $5 \%$ of the problem solving skills.

The Increased Awareness Levels of the KGBVs on Life Skills in Critical Thinking

Table 8: Effect of Life skills training on Critical thinking

\begin{tabular}{|c|c|c|c|c|c|c|c|c|c|}
\hline \multicolumn{10}{|c|}{ Critical thinking } \\
\hline \multirow{2}{*}{ Test } & \multicolumn{3}{|c|}{$\mathbf{1 0}^{\text {th }}$ class } & \multicolumn{3}{c|}{$\mathbf{8}^{\text {th }}$ class } & \multicolumn{3}{c|}{ class $^{\text {th }}$} \\
\cline { 2 - 11 } & Low & Average & High & Low & Average & High & Low & Average & High \\
\hline Pre test & 15 & 45 & 40 & 20 & 35 & 45 & 25 & 50 & 25 \\
\hline Post test & 10 & 35 & 55 & 15 & 45 & 40 & 20 & 40 & 40 \\
\hline
\end{tabular}

- Critical thinking in KGBVs students, before intervention it can be seen that in $10^{\text {th }}$ class students $40 \%$ having critical thinking In $9^{\text {th }}$ class $45 \%$ and $8^{\text {th }}$ class $25 \%$ having critical thinking.

- The intervention helped the students to increase their critical thinking. This can be seen in the graph $55 \%$ of the respondents in the $10^{\text {th }}$ class. In the $9^{\text {th }}$ and $8^{\text {th }}$ classes $40 \%$ having critical thinking. 


\section{The Increased Awareness Levels of the KGBVs on Life Skills in Interpersonal Relationship Skills}

Table 9: Effect of Life Skills Training on Interpersonal Relationship Skills

\begin{tabular}{|c|c|c|c|c|c|c|c|c|c|}
\hline \multicolumn{9}{|c|}{ Interpersonal relationship skills } \\
\hline \multirow{2}{*}{ Test } & \multicolumn{3}{|c|}{$\mathbf{1 0}^{\text {th }}$ class } & \multicolumn{3}{c|}{$\mathbf{9}^{\text {th }}$ class } & \multicolumn{3}{c|}{$\mathbf{8}^{\text {th }}$ class } \\
\cline { 2 - 11 } & Low & Average & High & Low & Average & High & Low & Average & High \\
\hline Pre test & 10 & 35 & 50 & 15 & 15 & 70 & 25 & 30 & 45 \\
\hline Post test & 20 & 15 & 80 & 10 & 15 & 75 & 20 & 25 & 55 \\
\hline
\end{tabular}

- Interpersonal relationship skills in KGBVs students. Before intervention it can be seen that in $10^{\text {th }}$ class students $50 \%$ having interpersonal relationship skills. In $9^{\text {th }}$ class students $70 \%$ and $8^{\text {th }}$ class students $45 \%$ of inter personal relationship skills.

- The intervention helped the students to increase their interpersonal relationship skills. This can be seen in the graph $80 \%$ respondents having high interpersonal relationship skills. In $9^{\text {th }}$ class $75 \%$ and $8^{\text {th }}$ class $55 \%$ of interpersonal relationship skills having.

\section{CONCLUSIONS}

The adolescent is the critical phase of life. It is a period of major physical, physiological, psychological and behavioural changes with changing patterns of social interactions and relationships. In order to help adolescents and youth better prepare for their adult world, they need life skills. Awareness must be created among parents on life skills on all the nine domains.

On the whole, life skills education, have found to be an effective psychosocial intervention strategy for promoting positive social, and mental health of adolescents which plays an important role in all aspects such as strengthening coping strategies and developing self-awareness Interpersonal relationship skills, as well as enhancing critical thinking, problem solving and decision making skills. To enhance the students' awareness level, equip them with better adapted skills to face the challenges of changing life situations and empower them to become fully functioning contributors to the host society in particular and the world in general.

By encouraging the students in KGBVs hold activities; they are enabled to strengthen their life skills. If such activities are accompanied by suitable classroom activities by teachers, the children and adolescents would acquire skills required for happy and healthy life. Mental health professionals directly or through teachers or parents should be involved in skill building exercises and promoting competence among adolescents.

\section{REFERENCES}

1. Arati Chakra and Aruna, Dr. M. 2016. Influence of family variables on core affective life skills youth. www.homesciencejournal.com/archives/207/vol3issue1/PartB/3-1-17.

2. Botvin, G., Griffin, K., Paul, E., and Macaulay, A. 2003. Preventing Tobacco and Alcohol Use among Elementary School Students Through Life Skills Training. Journal of Child \& Adolescent Substance Abuse, 12(4), 1-17. http://dx.doi.org/10.1300/j029v12n04_01.

3. Nair, M. 2005. Family Life \& Life Skills Education for Adolescents. Abstract, University of Southampton.

4. Chennat, S. Classroom Strategies For Developing English Language Skills In Children With Dyslexia At Elementary Level: An Analytical Study. 
5. Singh and Kaur,.2015. Assessment of life-skills of adolescents in relation to selected variableswww.ijsrp.org/research-paper0817/ijsrp-p6826.pdf.

6. Subashree and Nair,.2014. View full paper - International Journal of Scientific and Research...www.ijsrp.org/research-paper0817/ijsrp-p6826.pdf. 